Stanislovas Sinkevičius ${ }^{*}$, Gytautas Ignatavičius ${ }^{* *}$

Department of Natural Sciences of the University of Vilnius

\title{
Changes in the Natural Environment and Their Potential Impact for Lithuania
}

\begin{abstract}
The notion of the natural environment embraces a whole of functioning interrelated elements (land surface and subsurface, air and water, soil and biota, organic and inorganic matter, as well as anthropogenic components) and natural, semi-natural and human-made systems linking these elements. The state development and conservation of Lithuanian natural environment components and resources make the core of the problem that the state and the community encounters under the conditions of the integrated and advancing impact of climatic changes and anthropogenic (technogenic) activities. The current climate changes cannot be dissociated from the challenges by economic globalisation, depletion of energy and resources, abatement of poverty, social inequality and lack of security; therefore, partial solutions would not remove the problems endangering the stability of the future. Analysing the processes taking place in the environment is very important in order to reveal the basic causal relationships of the environment and the factors affecting it. We shall never be able to solve successfully the environmental problems without understanding the whole system of relationships between the cause and the effect.
\end{abstract}

\section{Introduction}

World scientists acknowledge that during last 200 years, the processes in the Earth's ecosphere (a wider term for the natural environment) have been unbalanced by human activities that turned into a factor of negative global impact on the environment. The technogenic expansion proceeding for the good of the every kind of progress is depleting the natural resources, changing the structure of environmental systems and the processes occurring there, thus, causing the deterioration of environment's quality that determines the existence and/or further evolution of human society. According to Ulrich Beck, the welfare of some human societies was created by an extensive use of nature resources and formation of ecological problems and environmental risk that, due to their technological origin, differed greatly from the former one, and all this leads to doubts about the institutional capability of modern

\footnotetext{
" Doc. dr. Stanislovas Sinkevičius is a head of the Centre for Ecology and Environmental Studies at the Department of Natural Sciences of the University of Vilnius. Address: M. K. Čiurlionio 21/27, LT- 03101 Vilnius, tel.+370-5-2398299, e-mail: stanislovas.sinkevicius@gf.vu.lt.

** Doc. dr. Gytautas Ignatavičius is a research fellow of the Centre for Ecology and Environmental Studies at the Department of Natural Sciences of the University of Vilnius Address: M. K. Ciurlionio 21/27, LT03101 Vilnius, tel. +370-5-239 8750, e-mail: gytisi@takas.lt.
} 
society to control the environmental risk penetrating into all spheres of the society ${ }^{1}$.

Of late decades, not only in the world and European Union (EU), but also in Lithuania, it is acknowledged that the global climate changes observed together with increasing anthropogenic impact is hazardous for the people, their living and, especially, the natural environment, as well as further development of the states. In Lithuania, the environmental changes are related to multiple economic and social effects on the state and its population ${ }^{2}$.

Changes in the global environment taking place due to climate changes inspire economic and social problems of two types. Firstly, the losses suffered directly from unfavourable environmental phenomena, anomalies or disasters. They are huge and difficult to be controlled and forecasted. Nevertheless, the programmes to fight against climate and environment changes often create also rather impressive economic and social problems. The implementation of these programmes is related to additional costs to introduce environmental solutions into production, technological constraints in selecting production mode, market sales problems, additional taxes and new changes in social sphere. It should be accepted that the payment the society begins to do for its "aggression" against the environment is the pay for its long-lasting nihilistic approach to the nature and the drain of nature potential.

Integrated investigations of environmental changes are being performed in the world, and their generalised results can be considered as an indirect indicator that can be used to forecast future changes in Lithuania's natural environment, where such investigations last a very short time. It should be noted that there are also some specific regional differences in spatial peculiarity, uniqueness and complexity of nature ecosystems and their components. As for Lithuanian landscapes, according to Prof. Kavaliauskas ${ }^{3}$, the geochemical (agricultural and urban areas), slope (urban areas), littoral (sea coast), karst (North Lithuania) and biogenic (various aquatic systems) processes seem to be the most relevant.

Nearly all global environmental problems in the world are reflected in a geographically small area of Lithuania (destruction of biological variety in the physical nature systems and their components, hyper-exploitation of nonrenewable and renewable resources, pollution of nature spheres with all the related consequences, as well as newly being formed and expanding phenomena not only in the environment, but also in certain social sphere units). Negative global anthropogenic impact is manifested not only via direct degradation of

\footnotetext{
${ }^{1}$ Beck U, Risk Society: Towards a New Modernity, London: Sage, 1992.

2 Nacionalinè mokslo programa „Lietuvos ekosistemos: klimato kaita ir žmogaus poveikis“, Bendrosios nuostatos, 200801 15, projektas, Vilnius, VU Ekologijos institutas, 2008. [National Science Programme "Lithuania's Ecosystems: Climate Changes and Human Impact", General provisions, 1501 2008, draft, Vilnius, VU Ecology Institute, 2008] (in Lithuanian)

3 Kavaliauskas P., „Kraštovaizdis“ ['Landscape'] in ,Lietuvos gamtinè aplinka, būklè, procesai ir raida“ [Lithuania's Natural Environment, State, Processes and Development], Aplinkos apsaugos agentūra [Environment Protection Agency], Vilnius, 2008, p.p. 102-103.
} 
the natural environment, but also via other indirect mechanisms causing longterm and often irreversible changes. One of them is the global climate change initiating a chain of conversions, restructurings and adaptations. It should be noted that these changes proceed in a differently way and in a rather small spaces, such as areas of ES member states.

The climate changes are related, first of all, to the additional emissions of gases, increase of their content in the atmosphere and related greenhouse effect. The Intergovernmental Panel on Climate Change (IPCC) established by the United Nations (UN) World Meteorological Organisation (WMO) presented the report on the emissions of greenhouse gas and other climate-affecting ones, where four potential development scenarios (A1, A2, B1 and B2) are given ${ }^{4}$. These scenarios for the emission variations are based on the projection of social and economic development of the mankind, depending on the ability of certain states to introduce and adapt modern technologies and other institutional novelties in order to change the impact on the natural environment. Scenario A1 projects very rapid economical growth, increase in population by mid- $21^{\text {st }}$ century followed by a decrease, and sharp introduction of modern technologies.

Three subgroups are distinguished here (A1F1 - prevailing burnt nature resources which are not fast recoverable, $\mathrm{A} 1 \mathrm{~T}$ - prevailing burnt nature resources which are fast recoverable, and A1B - balanced fuel use is planned). Scenario A2 projects a highly heterogeneous world with constantly growing population, slow economical growth, and new technologies being introduced only in some better developed regions. Scenario B1 models a rapid globalisation with population growth similar to that in Scenario A1B, but the economic system turns very fast into an informational and less consumer-type society with intensive introduction of new clean technologies. According to Scenario B2, the world is oriented to a more active integrated solution of local economic, social and environmental problems. The highest greenhouse gas content is predicted to be in the case, if the mankind developed according to the Scenario A2, while the implementation of Scenario B1 would cause small changes in the climate sphere. Nevertheless, the intermediate Scenario A1B is most realistic, being a bit closer to Scenario A2.

The data presented by the above scenarios embrace the GCM (General Circulation Model) input data used by world climate research centres to model future climate changes. Global models HadCM3 (by Hadley Climate Research and Forecast Centre in the United Kingdom) and ECHAM5 (by Max Planck Meteorology Institute and German Climate Calculations Centre) are most often used to forecast climate in separate European regions. According to Dr. Rimkus, the output results of the three scenarios (A1B, A2 and B1) models were used for prognostication of Lithuania's climate. However, the size of the climate model grid cell was too large that regional variations in Lithuania's climate were reflected in the forecasts. In order to make a transfer from the global scale to the local one, the statistical enhancement of the model grid resolution was

4 Nakicenovic N., Swart R., (eds)., Special Report on Emissions Scenarios, 2000, www.ipcc.ch/pub/ reports 
performed with the linear and multiple regression method applied. Forecasts of climate indices for the 21st century have been made for 16 meteorological stations in Lithuania. In order to show the range of potential changes, the forecasts on air temperature, precipitation and wind direction are given according to the HadCM3 model Scenario A1B (large changes predicted) and ECHAM model Scenario B1. Data obtained by Prof. Bukantis and Doc. Rimkus air temperatures according to HadCM3 model Scenario A1B should grow alrea$\mathrm{dy}$ in the first three decades of the $21^{\text {st }}$ century (if compared to the 1971-2000 average). In winter, air temperature should rise in all Lithuania by $1.3^{\circ} \mathrm{C}$; in maritime area they become positive $\left(0.5^{\circ} \mathrm{C}\right)$, while in east Lithuania, remaining negative, they are to rise to $-3.1^{\circ} \mathrm{C}$. In spring, the air temperature would rise just by $0.5^{\circ} \mathrm{C}$ to $6.2-7.4^{\circ} \mathrm{C}$. In summer air temperature is to rise by $0.6^{\circ} \mathrm{C}$; air temperatures in the Žemaitija Upland and east Lithuania are to be $16.2^{\circ} \mathrm{C}$ and $16.6^{\circ} \mathrm{C}$, correspondingly, and the major part of Lithuania is to be under temperatures higher than $17^{\circ} \mathrm{C}$. In autumn, average air temperature changes will be more significant in the western part of Lithuania with $0.9-1.2^{\circ} \mathrm{C}$ rise, while the air in other areas will be warmer by $0.4-0.8^{\circ} \mathrm{C}$. The average autumn air temperature in the maritime region would be close to $10^{\circ} \mathrm{C}$, whereas east Lithuania would see $6-7^{\circ} \mathrm{C}$. According to ECHAM5 model emission Scenario B1 lower changes in air temperature are predicted. Air temperature in winter is to rise by $0.8^{\circ} \mathrm{C}$; air temperatures ranging between 0 and $-2^{\circ} \mathrm{C}$ would prevail in the major part of the most area and about $-3.5^{\circ} \mathrm{C}$ would hold in the eastern part. Spring temperature is to rise by $0.2-0.3^{\circ} \mathrm{C}$ in average. In summer and autumn, air temperature would grow by $0.3^{\circ} \mathrm{C}$ and $0.5-0.7^{\circ} \mathrm{C}$ in average. According to HadCM3 model Scenario A1B, during the nearest three decades winter precipitation would increase by $6 \mathrm{~mm}$, in average, in all area of Lithuania. The biggest changes $(8-9 \mathrm{~mm})$ are projected for the southeast area and the Žemaitija Upland, where winter precipitation would reach $140-180 \mathrm{~mm}$. The increase in spring precipitation should be smaller-3 $\mathrm{mm}$, while the southeastern part should see a slight decrease in precipitation. Summer and autumn precipitation would decrease in all of Lithuania by $6-7 \mathrm{~mm}$ per season. In maritime area, precipitation changes would be smaller. With air temperature rising, the number of days with snow cover is to decline. During the nearest two decades, the period with snow cover would become shorter even by 10-15 days. Probability of formation of constant snow cover also would go down: about the year of 2030, snow cover in the maritime region is expected to occur once in $4-5$ years, and the probability of constant snow cover in the eastern part would decrease to $70 \% .^{5}$ Et. $^{6}$

The present-day climate system became more complicated because due to the reduction of self-regulating ecosystems, such as global forests, and rapid

\footnotetext{
5 Bukantis A., Klimato kaitos priežastys \{Causes of Climate Change]. In „Globali aplinkos kaita”, Vilnius, 2007, p.p. 77-105

${ }^{6}$ Rimkus E., Klimato kaitos prognozės (Prognoses of Climate Change]. In „Globali aplinkos kaita”, Vilnius, 2007, p.p. 107-132.
} 
expansion of agricultural and urban areas providing increasing pollution and additional greenhouse gas emissions, the Earth's ozone layer goes thinner, alternations in hydrological systems and soils speed up, irreversible changes in biological variety take place, while human health becomes more vulnerable. With awareness and consciousness of the growing society, of late decades, the understanding of environmental pollution in a whole world is related to intensification of the society's approach to global climate change and its results and radical reappraisal of consumer-type values taking into account the requirements raised by the sustainable development and prevention of climate changes. Several decades ago scholars and environmentalists of different countries paid their emphatic attention and efforts to the analysis of separate climatic anomalies and their aftermath, the protection of nature and civilisation values; however, the last decades of the $20^{\text {th }}$ century due to increasing scale of environmental pollution and more often appearance of nature anomalies and disasters followed by serious losses and threats for security of people, the necessity emerged to make an integrated study on the causes and results of climate changes and their consequences (European Commission, 2008) ${ }^{7}$.

Based on the data available in Lithuania and the world on climate change monitoring and further development, it is still difficult to make impartial determination which natural environmental processes related to human activities and climate changes are most important in Lithuania, and what consequences of these processes can be expected to have on the environment and the man.

Often the question appears: what is the monetary expression of losses and additional costs suffered by the society of a state due to inevitable consequences of changing natural environment. According to EU experts, there is some estimation that the damage caused by inactivity can reach $5 \%-20 \%$ of the global Gross Domestic Product (GDP) per year, whereas the proper investments into clean technologies by the year of 2050 would demand only $0.5 \%-1 \%$ of the global annual GDP with the additional benefit for nature and human health obtained. There is no single answer to a question: How much would mankind and Lithuania spend to prevent climate changes? Looking from the short-term assessment positions, climate change might be useful for such economy spheres as agriculture, tourism, utilities. But choosing this way we would take part in a race where life quality, security and competitive ability is set on a cast.

World scholars and authorities in this field acknowledge that the models and studies of this problem are based on a series of reservations and the principle "if", hence, causing their conventionality and programmed digression from real situation ${ }^{8}$. Such conventionality is caused by intricacy of differential

\footnotetext{
${ }^{7}$ Europos Komisija, Vyriausiojo igaliotinio ir Europos Komisijos dokumentas, Europos Vadovu Tarybai. Klimato kaita ir tarptautinis saugumas, [European Commission, Document of High Representative and European Commission, European Council, Climate Change and International Security], 2008, www. consilium.europa.eu/ueDocs/cms Data/docs/pressData/LT/reports/99402.pdf.

${ }^{8}$ Using the ODD protocol for comparing three agent-based social simulation models of land use change., Polhill, J.G.; Parker, D. C.; Brown, D.G.; Grimm, V., Journal of Artificial Societies and Social Simulation, 2008, 11(2).
} 
equation systems used in mathematical models and simplification of multifactor interactions to elementary linear equation coefficients.

In spite of the above reasoning about the complicacy in the financial assessment of the losses and preventive measures, in general it is acknowledged that the man will pay a very high price for his careless invasions into the nature done in the past and often continuing even now; and exact figures of losses in the future will depend on the way the mankind is to choose now. If we manage to turn our economical and social development and reorient our demands towards the sustainable development, the losses will decrease and we shall be able to control the negative consequences of global change in the environment. Otherwise, the most pessimistic scenarios of the future can be realised-even the decay of civilisation on the Earth.

\section{Global Climate Change and Its Threats on the Natural Environment}

The impact of climate change on a global scale is observed already now: global geochemical cycles of basic substances are disturbed, thus, causing the rise in temperature, melting and shrinking glaciers in the mountains, ice fields in polar and sub-polar shelf areas, extreme meteorological phenomena are not only more often manifesting, but they are more intensive and their geography is changing. The forecasts show that after 90 years, average global temperature can exceed that fixed in 1990 , i.e. $1.4-5.8^{\circ} \mathrm{C}$. Temperature changes on inland areas will be bigger than on the sea and growing with the higher latitudes. The amplitudes of their diurnal, seasonal and long-term variations will also grow, as well as precipitation distribution in time and space will change ${ }^{9}$.

A northward movement of various biological species areas- $6.1 \mathrm{~km}$ per a decade-is observed in northern continents. Many experts predict that the taiga forests can shift northwards by several hundred kilometres, while the tundra zone will shrink and its role as a biome area will be less significant. The permafrost disappearing in tundra will set the gases accumulated there, thus, providing additional impulse for greenhouse effect in the climate sphere. Rapid degradation of Alpine ecosystems is expected, and the rest $84 \%$ of coral reefs can vanish. Even $85 \%$ decrease in area of various wetland ecosystems is possible. Desert areas will expand and occupy the present areas of savannah and land eroded due to improper farming. Being unable to leave the unfavourable climate zone and resist against more frequent fires, forest areas can shrink as well.

9 Mc Carthy et al., (eds), Climate Change 2001: Impacts, Adaptation and Vulnerability. Contribution of Working Group II to the Third Assessment Report of the Intergovernmental Panel on Climate Change, Cambridge University Press., 2001 
At present time, the fact of climate change raises no doubts and is generally acknowledged (discussions take place only on the reasons, development and potential consequences). To control its intensity is a long process; therefore, it is necessary to create environment management strategies of new quality, which should include not only the reduction of climate change intensity and elimination of causes, but also the control of its outcomes with simultaneous protection of nature values and population.

Environmental problems are notable for their global character, and they cannot be solved at the level of a certain enterprise or a production process, this should be done in a complex way at the level of cities, industrial districts, regions, a state or a group of states. Another important feature in dealing with climate change problem is that it must be considered a complex one. Its complexity is caused by intricacy of a system, since it is determined by three components: natural environment, society and production. Moreover, the development of the system is impossible without a comprehensive assessment of social, environmental, technological, legal and international aspects. ${ }^{10}$

The climate change-caused risk is real, and the outcomes of its impact are global. A report presented by a UN Commission in 2007 shows that all, except one, urgent appeals for humanitarian aid were related to climate. The IPCC conclusions show that even if by 2050, the emission of pollutants into the atmosphere was reduced to the level lower than a half of the 1990 year level, it would be difficult to avoid temperature rise by $2 \mathrm{rC}$ if compared to that before the industrialisation. Such a rise of temperature will cause serious security risk that will grow further, if the warming continues. Without the mitigation of climate change, temperature will rise by more than $2 \mathrm{rC}$ and unprecedented problems of security will appear, since there will probably be not the only crucial change that will cause acceleration of climate alternations, which will become irreversible and often unpredictable. In order to avoid such scenarios, the investments into the mitigation of the impact as well as measures of adaptation to the inevitability should be an imperative in solving the problem of threats caused by climate change to international security; and both should be considered a preventive part of security policy ${ }^{10}$.

The best way to assess the climate change is to treat it as a threat factor enhancing the present tendencies, stress and instability. A key difficulty is that the climate change is to cause additional burden to the states and the regions, which already are vulnerable and conflictive. It is important to understand that the rising risk is not only of humanitarian character; it is also related to political and security risk having direct impact on European interests. Moreover, taking into account the human security concept, it is obvious that the majority of issues related to the impact of climate change on the international security are interconnected and to solve them an integrated policy is necessary. For instance, there is a serious risk to achieve the Millennium Development goals, since the developmental activities performed for years can lose its sense, if the climate change is not mitigated. Among the key factors mentioned there are such as population variations, energy

${ }^{10}$ Ed. by Pachauri K et al., Climate change 2007. Synthesis Report,. WMO, 2007, 104 p. 
consumption, peculiarities of technological development with a further scatter of emerging processes in some world regions takes concrete forms as:

- Local and interstate conflicts for nature resources use and control;

- Economic damage brought by sudden floods on coastal towns and rising risk for infrastructure units of primary importance;

- Loss of a territory and disputes on borders;

- Population migration due to environmental problems;

- Vulnerability and radicalisation situations;

- Strains due to energy resources and supply of energy;

- Pressure on international control system.

The importance of land use changes and environmental policy also should be mentioned. The objective to minimise the intensification of climate change due to human activities and control negative environmental, social and economic consequences caused by this phenomena with minimum negative impact on the man prompts to make differently oriented political solutions, which might be of both adaptive (accommodating to natural systems or social-economic) and mitigating (minimising various-type human impact on the environment, e.g. gas emission, reduction of highly hazardous pollution).

However, even if the best and most efficient measures of climate change mitigation are implemented, the climate change and related impact on different spheres will not cease. Therefore, in order to safeguard secure functioning of economic, social and environmental spheres it is necessary to elaborate and implement adaptation to climate change strategies. The implementation of such national strategies would enhance the resistance to the impact of climate change.

\section{Some Aspects of Natural Environmental Changes in Lithuania}

\subsection{Assessment of Lithuania's Economic Growth in the Climate Change Context}

Historically, quite a few years have passed in Lithuania since the restoration of its independence, but there is a fundamental turn in its national economy. Initially, a rather serious slump was suffered (Fig. 1) with hyperinflation and unemployment, starting emigration, and when the economy began to recover, there was a negative affect due to Russia's economic crisis. In about 2002, new tendencies showed up-a rapid rise in consumption, and a decrease in unemployment. From 2003, the development of internal demand and exports as well as a boom gaining momentum lead Lithuania to a European leader according to the growth of GDP and the unemployment rate decrease. 


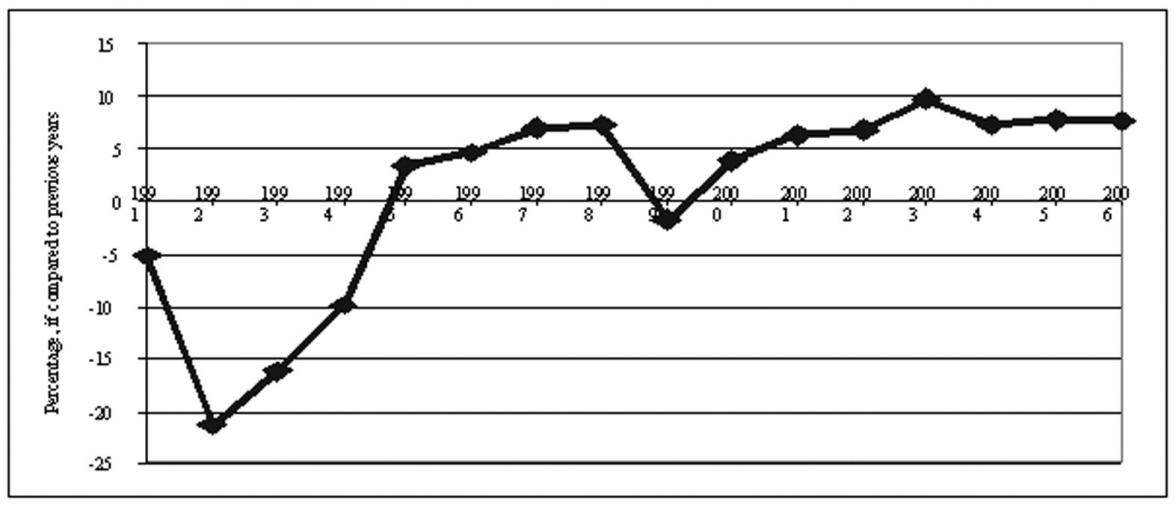

Figure 1. Gross Domestic Product percentage variations ${ }^{11}$

Unfortunately, the world economic crisis did not bypass Lithuania, and the changes in its social-economic spheres (especially energy) will affect climate change mitigation for long years.

When assessing the impact of Lithuania's economy on the climate change there is another very important thing which should be talked about, i.e. the structure of the national economy. It is rather diversiform, but it has significantly changed during the independence years (Fig. 2)-a major part of GDP is being formed by the spheres of services and high technologies, whereas the part of energy- and raw material-consuming industries decreased significantly.

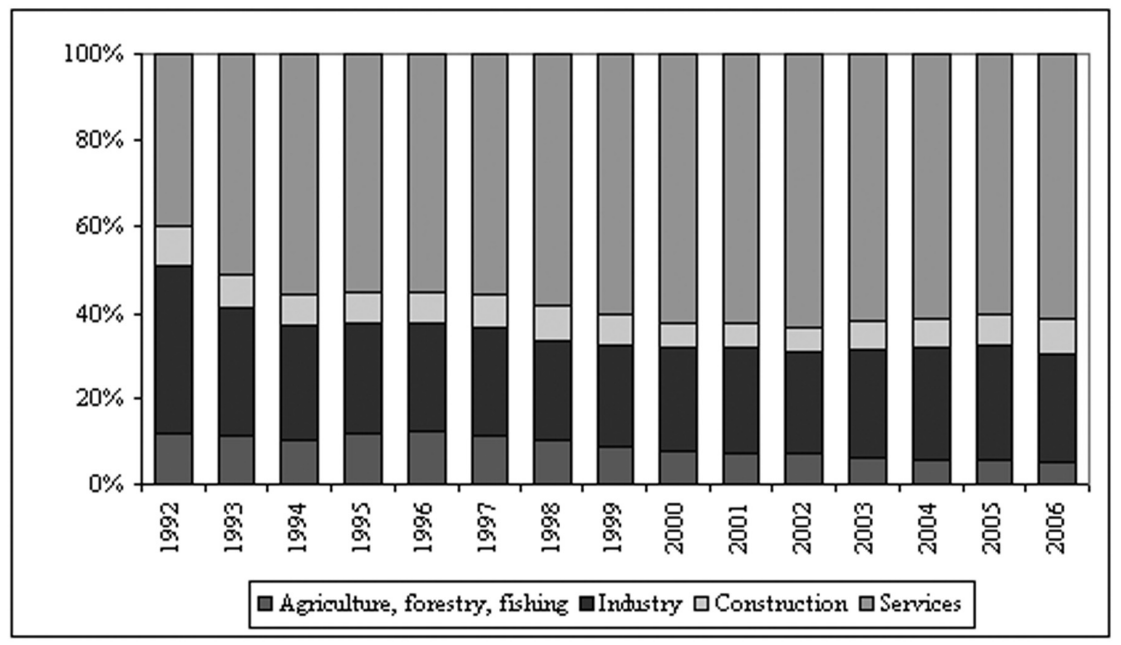

Figure 2. Gross Domestic Product structure in Lithuania ${ }^{12}$

\footnotetext{
${ }^{11}$ Data source: Statistics Department.

${ }^{12}$ Data source: Statistics Department.
} 
Speaking about energy, the problems due to Ignalina Nuclear Power Plant (INPP) closure and the related increase of greenhouse gas emission should be especially noted. During the last five years the INPP produced from $77 \%$ to $85 \%$ of the total electric power in Lithuania. After INPP is closed at the end of 2009 , the consumption of air-polluting oil and gas will increase in the initial energy balance. Since oil and natural gas are considerably more polluting the environment, from the greenhouse gas emission viewpoint, consequentially, the emission of greenhouse gas in Lithuania is thought to grow and the contents of this gas is expected to grow by $9 \%$ in 2010, and after ten more years the emission would be by 28 percent higher than that in 1990 (Fig. 3).

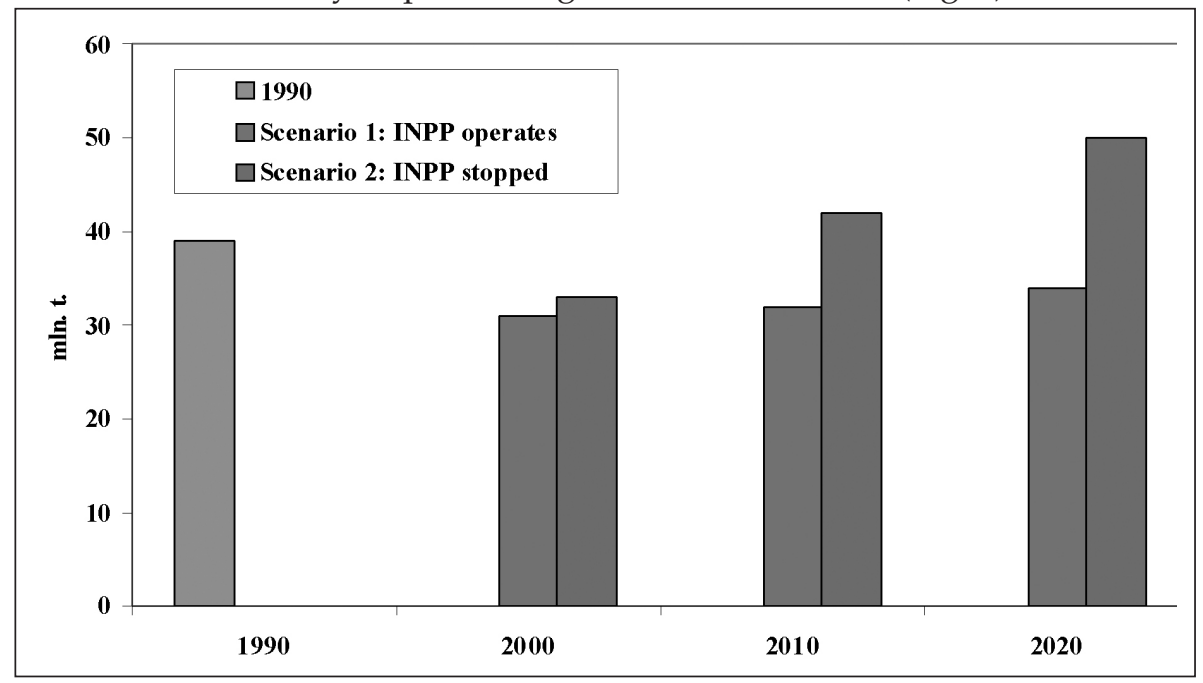

Figure 3. Carbon dioxide $\left(\mathrm{CO}_{2}\right)$ amounts and their forecast in Lithuania ${ }^{13}$

On January 18, 2007 Lithuanian parliament Seimas approved the energy strategy, the fourth one from the restoration of independence, with the stress laid upon strategic priority goal to build a new nuclear power plant by 2015 . If the EU energy bridges are not taken into account, before 2015, the basic fuel for the Lithuanian Power Plant might be natural gas from Russia or black oil, as a reserve version, also from Russia and partly from Belarus, Venezuela or some new sources. Therefore, in order to reach maximum mitigation of greenhouse gas emission growth, a great regard is to be paid to the use of renewable power sources in Lithuania's energy system. In this respect, focal attention is given to power production from wind, water and biomass in the energy sector

13 Jaskelevičius B., Žiugžda V., Energetika ir atmosferos tarša Lietuvoje, Lietuvos mokslas ir pramonè: Šilumos energetika ir technologijos, KTU pranešimų medžiaga, 2001 vasario 1-2 d., Kaunas ['Energy and Atmospheric Pollution in Lithuania, Lithuanian Science and Industry': in Heat Energy and Technologies, KTU Conf. Reports, 1-2 February, 2001, Kaunas], Technologija, 2001, p. 249-252 (in Lithuanian). 
and fuel production from a biomass in transport sector ${ }^{14}$. The best prospects in Lithuania's future energy system by 2010-2020 seem to be linked to wind and water power that would comprise, respectively, up to $39 \%$ and $50 \%$ from all renewable energy resources.

The present priorities in the Environment Protection Policy of Lithuania are closely related to sustainable development in Lithuania, i.e. the reduction of impact from basic economy branches on the environment and human health, mitigation of global climate change and its consequences. So, special heed is paid to the climate change. The National Sustainable Development Strategy, approved in 2003, envisages improvement of environment quality assessment and control systems in order to safeguard the air quality needed for human health and ecosystems in all area of Lithuania.

\subsection{Lithuanian Climate Change Prognoses in 21st Century}

Lithuanian climate variations are a part of the processes taking place in the whole climate system of the world. Thus, Lithuania is potentially open for both global climate variations and the results achieved reducing greenhouse gas emissions.

Lithuania's climate is caused by zonal (global) factors and local geographical conditions (azonal factors). The zonal factors include geographical position of Lithuania and prevailing air mass transport from the west in all troposphere and lower part of stratosphere. Features of Lithuania's climate depend on distribution of adjacent land areas, oceans and seas, absolute height of relief, soil properties, and underlying surface type. West of Lithuania, there are huge areas of the Baltic Sea and the Atlantic Ocean and rather small land areas-Scandinavian and Jutland peninsulas with islands. East of Lithuania the Eurasian continent stretches for several thousand kilometres. Hence, Lithuania is constantly receiving pollutants from the west with the air mass transport.

In spite of the fact that there are quite a few prognostic scenarios and models of climate change in the world, it should be acknowledged that none of them can depict real development scenario instead of hypothetic one $e^{15}$. Therefore we shall rely in this chapter upon data and conclusions by the authoritative Lithuanian researchers. Studies on climate change records and its prognostication have been consistently carried on in Lithuania from the past

\footnotetext{
${ }^{14}$ Katinas V., Atsinaujinančių energijos išteklių vartojimas energijos gamybai ir plètros galimybès Lietuvoje,, LEI. pran. konferencijoje „Šilumos energetika ir technologijos“. KTU, 2006 m. vasario 2-3 d. ['Use of Renewable Energy Resources to Produce Energy and Development Potential in Lithuania' LEI Conf. Reports: in Heat Energy and Technologies, KTU, 2-3 February, 2006], (in Lithuanian).

${ }^{15}$ Gómez-Hernández, J.J., Complexity or stochasticity? Proper labels and ways to handle uncertain inputs in environmental modeling. Report on NATO ASI Uncertainties in environmental modelling and consequences for decision making. Vrsar (Croatia) September 30-October 10, 2007.
} 
century. ${ }^{16}$ The results are published in the research transactions $,{ }^{17}, 18,{ }^{19},{ }^{20},{ }^{21}$ and all they contain clear scientific opinion that the climate in Lithuania is changing and will be changing in the future.

According to climatological data, mean annual air temperature in Lithuania indicates a rapid warming of the climate. The most clear warming trends are seen in the north and west parts of Lithuania. Mean annual air temperatures show obvious growth, depending on their topographical position (Fig. 4).

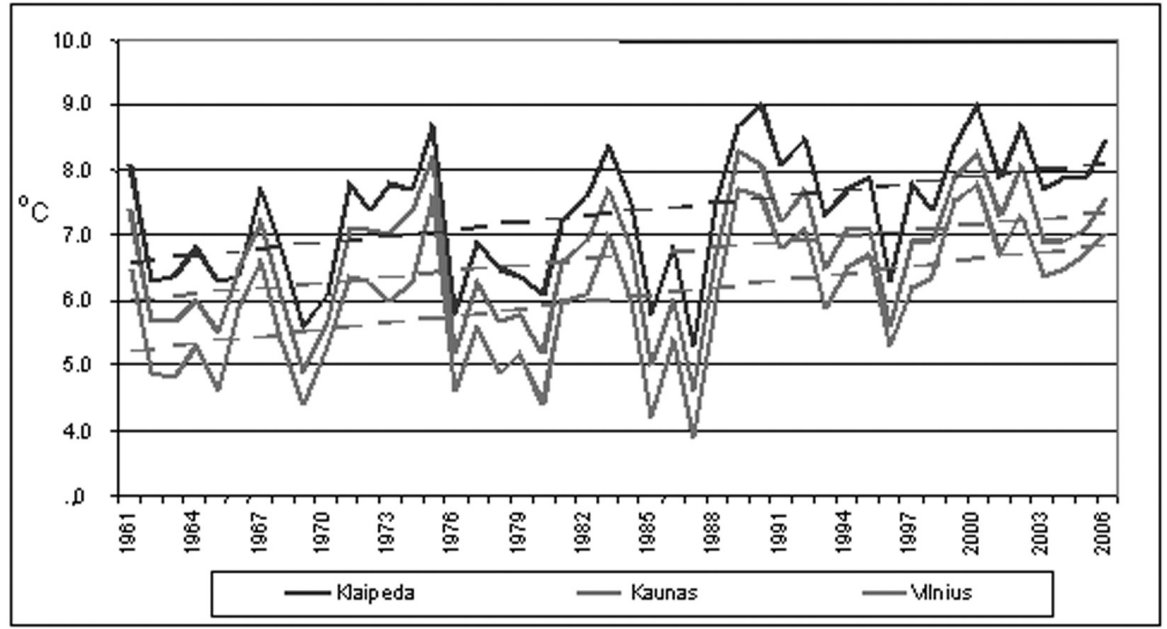

Figure 4. Mean annual air temperature and linear trends of its variation (dash line) in Klaipedda, Kaunas and Vilnius in 1961-2006 22

\footnotetext{
${ }^{16}$ Rimkus. E., Klimato kaita: modeliai, prognozės, faktai. Geografijos metraštis,T 32, Vilnius, 1999, p.p. 16-25.[Climate Change: Models, Prognoses, facts. Geographical Yearbook, 32] in Lithuanian.

${ }^{17}$ Rimkus E., Analysis of winter climatological indices change in Vilnius (1893-1995). Proceedings of the international conference on climatic dynamics and the global change perspective, Cracow, 1995, p. 309-312.

${ }^{18}$ Bukantis A., Rimkus E., Lietuvos agroklimatinių išteklių kaita ir prognozės, Lietuvos klimato ir dirvožemio potencialo racionalaus naudojimo perspektyvos, Mokslinès konferencijos pranešimai, Vilnius, 1997, p. 5-11. [Lithuanian Agroclimatic Resources Change and Prognoses, Perspectives of Rational Use of Lithuanian Climate and Soil Potential, Sci. Conf. Report (in Lithuanian).

${ }^{19}$ Bukantis A., Rimkus E. The Lithuanian climate in the 18th-21st centuries. Long term ecological research Baltic conference, 2004, p.14.

${ }^{20}$ Bukantis A. Climatic fluctuations in Lithuania against a background of global warming, Acta Zoologica Lituanica, vol. 11 (2), Vilnius, 2001, p. 113-120.

${ }^{21}$ Bukantis A., Valiuškevičienė L., Oro temperatūros ir kritulių kiekio ekstremumai, Meteorologija ir hidrologija Lietuvoje: raida ir perspektyvos, Mokslines konferencija, Vilnius, 2005, p. 29-30. [Air Temperature and Precipitation Extreme, in Meteorology and Hydrology in Lithuania: Development and Perspectives, Sci. Conf.] (in Lithuanian).

${ }^{22}$ Data source: Lithuanian Hydrometeorological Service.
} 
Analysis of monthly air temperature variations showed that in 1991-2006 mean air temperature nearly in all months was higher than that in 1961-1990. Cooler weather in all Lithuania was only in November $\left(0.1-1.0^{\circ} \mathrm{C}\right)$, in the maritime region this was also in October and December $\left(0.1-0.8^{\circ} \mathrm{C}\right)$. The Žemaitija Upland cooled down in May, October and November $\left(0.1^{\circ} \mathrm{C}\right)$. The highest increase of mean air temperature was observed in January, February, April, July and August $\left(1.3-2.5^{\circ} \mathrm{C}\right)$ (Fig. 5). This is also related to precipitation distribution and amounts.

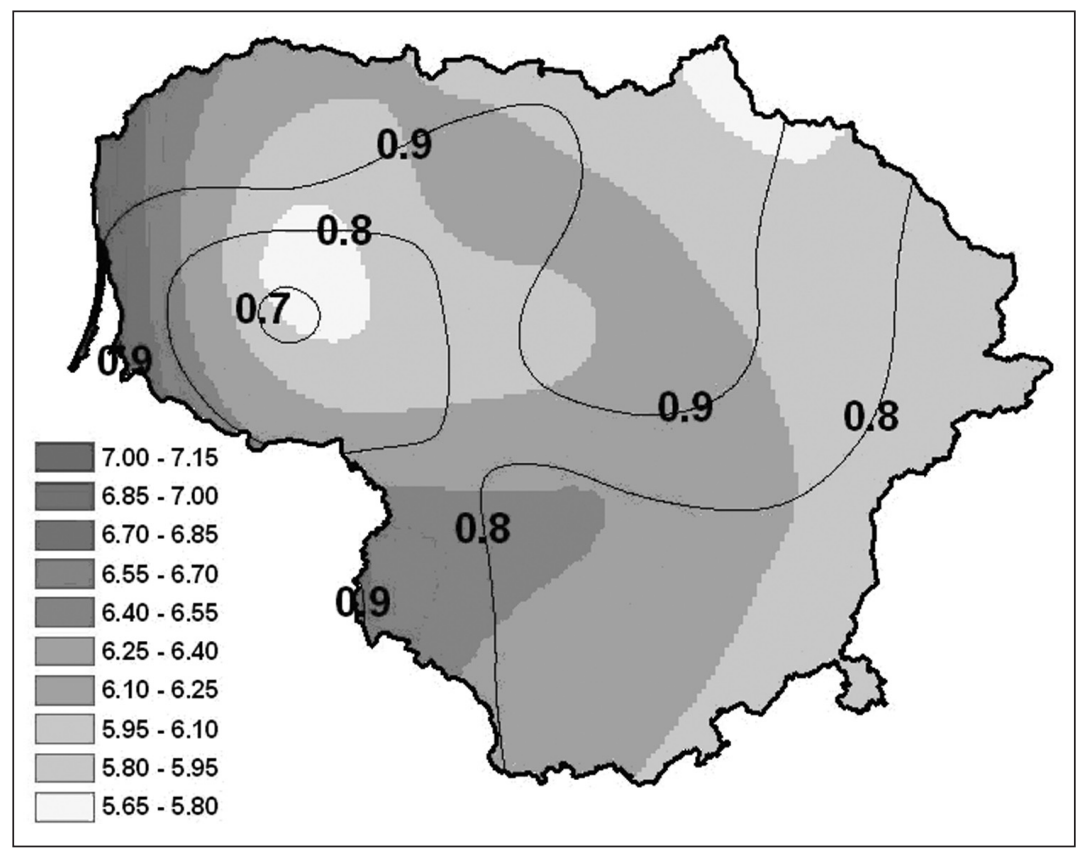

Figure 5. Mean annual air temperature $\left({ }^{\circ} \mathrm{C}\right)$ in $1961-1990$. The isolines show air temperature difference $\left({ }^{\circ} \mathrm{C}\right)$ between $1961-1990$ and $1991-2006 .{ }^{23}$

Of late decades, the probability of air temperature extremes is also rapidly changing. Heat above $30^{\circ} \mathrm{C}$ (maximum diurnal air temperature) and cold down $-20^{\circ} \mathrm{C}$ (minimum diurnal air temperature) causes risk for human health and damage to nature, transport, agriculture and other economic sectors. At the end of $20^{\text {th }}$ century number of extremely hot days began to increase. Their probability in 1991-2006, if compared to that in 1961-1990, showed a 2-2.5-fold increase and lasted 2-6 days per year. Their highest probability was observed in south and southwest regions of Lithuania, i.e. $4-6$ days per year. At the same time, number of frosty days in Lithuania decreased considerably: if in 1961-1990 such days happened 12-15 times per winter in eastern regions, of later years

${ }^{23}$ Data source: Lithuanian Hydrometeorological Service. 
this was observed only 8-9 times per season. Probability of frosty days in the maritime region decreased to 0.5 in winter, i.e. the frost is probable there only once in two years. Changes in probability of heat and frost are related to more frequent repetition of anticyclone processes in summer and rarer in winter.

According to scientific forecasts, air temperature in $21^{\text {st }}$ century will rise further, but unevenly in different seasons. Depending on global social and economic development scenario to be performed, mean annual temperature in Lithuania is to rise by $2-5^{\circ} \mathrm{C}$. Especially big changes are expected in winter with this season's mean air temperature to rise by $4-8^{\circ} \mathrm{C}$. The biggest temperature changes are expected to be in the maritime region and on the southern slopes of the Žemaitija Upland. The changes will be bigger than those forecasted for Central and West Europe, but smaller than in Scandinavia and North-East Europe. ${ }^{24}$ This is expected to affect social, economic and energy sectors.

The least air temperature changes are forecasted for summer with the season's mean air temperature to rise just $1.5-3^{\circ} \mathrm{C}$. However, assessing the changes from the viewpoint of normal distribution, the air temperature alterations in summer will not give up to those in winter and in many cases, they show two-fold excess above the mean square deviation. At the end of the $21^{\text {st }}$ century, mean temperatures of summer months in Vilnius and Klaipeda will range in $18-20^{\circ} \mathrm{C}$.

Distribution of precipitation in Lithuania depends mainly on the relief, slope position in regard to prevailing air streams and the distance from the sea. Therefore the mean annual precipitation level in Lithuania ranges from 850-900 $\mathrm{mm}$ on the windward slopes of the Žemaitija Upland to $570-590 \mathrm{~mm}$ in the Central Lithuanian plain. Average precipitation amount is about $675 \mathrm{~mm}\left(44 \mathrm{~km}^{3}\right)$.

Mean annual precipitation in 1991-2006, if compared to that in 1961-1990, decreased by $12-56 \mathrm{~mm}$ in western and central regions of Lithuania, while it rose by 20-66 $\mathrm{mm}$ in southern and north-eastern regions (Fig. 6). The precipitation in the warm season was found to decrease, while that of cold season was observed to rise in all Lithuania, except for the Žemaitija Upland. The biggest changes in precipitation amount were observed in the maritime region during warm season $(-9 \%)$, in the Žemaitija Upland and central Lithuania during cold season (respectively, $-10 \%$ and $+9 \%$ ). Precipitation during different months in 1991-2006, if compared to 1961-1990, varied differently: in all Lithuania precipitation decreased in September, November and December, and rose in January, February and October. Other tendencies in precipitation variations are of regional character. So, the July precipitation in the western region of Lithuania decreased even by $18-35 \%$, while the June precipitation in central and eastern regions of Lithuania decreased by $21-22 \%$.

\footnotetext{
${ }^{24}$ Solomon S., Qin D., Manning M., Chen Z., Marquis M., Averyt K. B., Tignor M. Miller H. L. (eds.), IPCC, 2007: Climate Change. The Physical Science Basis. Contribution of Working Group I to the Fourth Assessment Report of the Intergovernmental Panel on Climate Change. Cambridge: Cambridge University Press, 2007.
} 


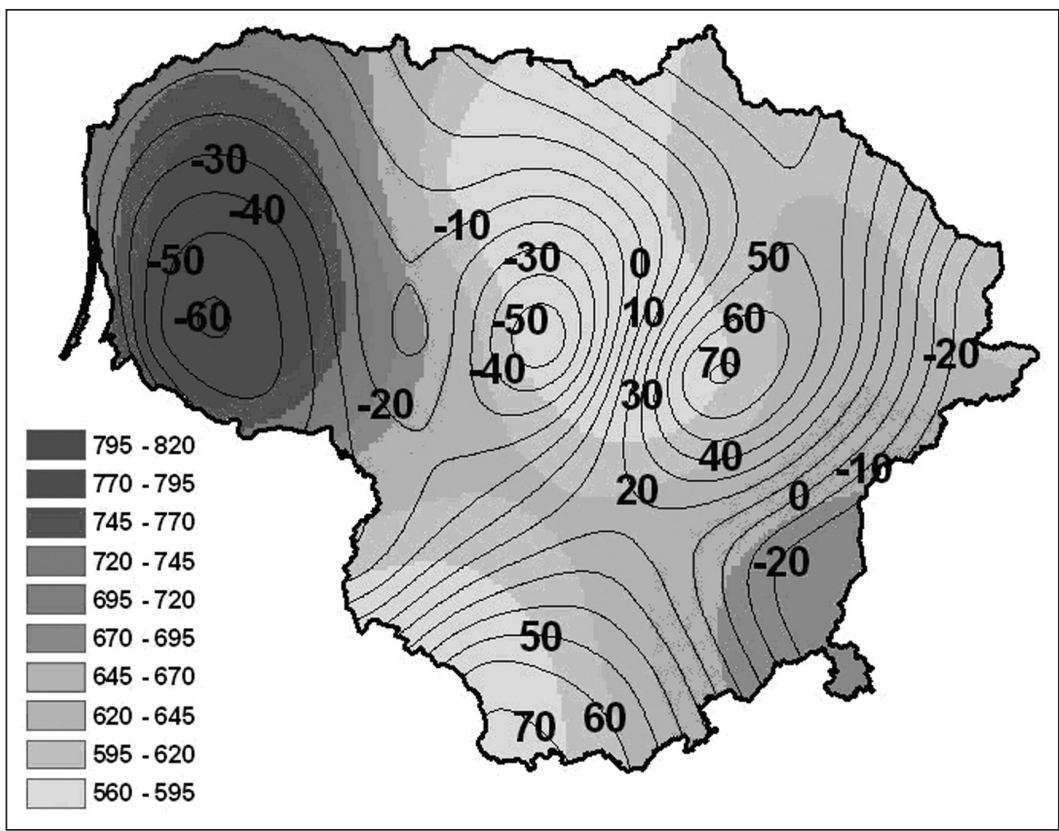

Figure 6. Mean annual precipitation ( $\mathrm{mm}$ ) in 1961-1990 m. Isolines show mean annual precipitation difference $(\mathrm{mm})$ between 1961-1990 and 1991-2006

Making forecasts on precipitation during the present century, Lithuanian researchers acknowledge that precipitation is one of the most varying meteorological elements that depends greatly on a year's season and a society development scenario used. Subject to behaviour of the society and its development in the future, different prognoses are made: some scenarios forecast increase in mean annual precipitation by $30-85 \mathrm{~mm}$, but also an opposite process might be observed, i.e. decrease in precipitation by $40 \mathrm{~mm}$. Nevertheless, all available climate change models for Lithuania show the rise in winter precipitation (from 5 to $60 \mathrm{~mm}$ per century) and less intensive increase in spring (from 5 to $38 \mathrm{~mm}$ per century). All the scenarios, without an exception, also show the decrease in precipitation in summer (to $0.3088 \mathrm{~mm} /$ year). In general, climate modelling results show that winter and summer precipitation should grow in all northern Europe and decrease in southern Europe; as for Lithuania being in an intermediate position, variations of different sizes are forecasted for different seasons.

Mean annual wind velocity (10 $\mathrm{m}$ above surface) in Lithuania is in the maritime region $(4.5-5.5 \mathrm{~m} / \mathrm{s})$, decreasing eastwards to minimum values $(2.7-3 \mathrm{~m} / \mathrm{s})$ in the forest and hilly districts of east and southeast Lithuania. Comparison of mean annual wind velocities for two periods-1971-1990 and 1991-2006-a slight tendency of wind weakening is observed, i.e. by $0.2-0.4 \mathrm{~m} / \mathrm{s}$.

${ }^{25}$ Data source: Environmental Ministry, Lithuanian Hydrometeorological Service. 
However, it is quite possible, that such changes could appear due to changes in the environment of the meteorological stations (build-up, forestation etc.), not because of peculiarities of atmospheric circulation. The most obvious weakening of wind $(0.5-1.1 \mathrm{~m} / \mathrm{s})$ was observed in Klaipeda at the end of summer and autumn. Maximum wind velocity in flows can reach $35-40 \mathrm{~m} / \mathrm{s}$ on the Baltic Sea coast or $25-28 \mathrm{~m} / \mathrm{s}$ in other areas of Lithuania. The maximum fixed wind velocity was $40 \mathrm{~m} / \mathrm{s}$. Most often and severe storms take place in October-January. Analysing maximum wind velocities in 1971-2006, no significant long-term change tendencies were observed Fig. 7). However, in 1999-2006 three cases were fixed on the coast, when wind velocity exceeded $30 \mathrm{~m} / \mathrm{s}$. While in 1971-2006, in total 8 cases of wind exceeding $30 \mathrm{~m} / \mathrm{s}$ were fixed. Thus, it can be assumed, that with warming climate the hurricane-level winds can be observed more frequently.

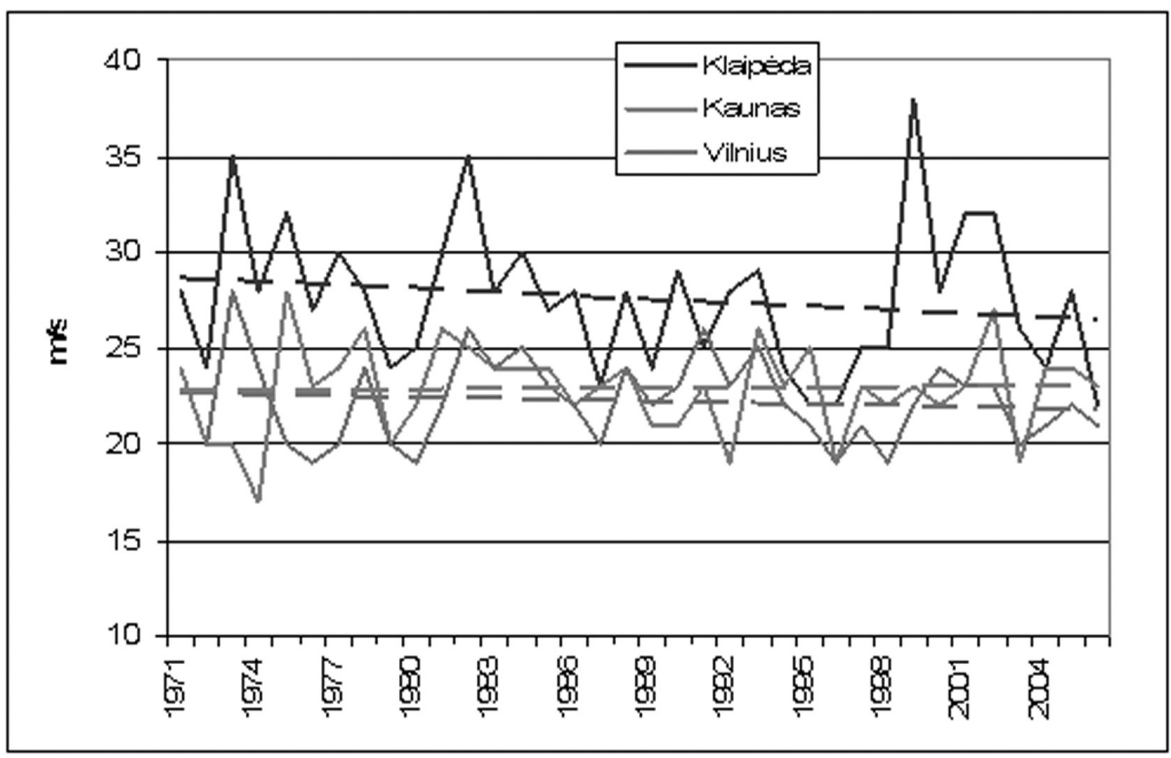

Figure 7. Maximum wind velocity in flaws $(\mathrm{m} / \mathrm{s})$ and linear trends of its variation in 1971-2006 ${ }^{26}$

In autumn and winter S, SW and W winds prevail in Lithuania, while in summer W and NW winds dominate. Comparison of mean frequency of wind directions between 1961-1990 and 1991-2006 m. showed that SE wind frequency in Lithuania decreased by $1.6 \%-4.5 \%, \mathrm{~S}, \mathrm{~W}$ and $\mathrm{N}$ winds became more frequent in the west and central Lithuania by $1.3 \%-4.5 \%$, W winds were less frequent in Klaipeda by $2.4 \%$, but SW, NE and E wind frequency increased here by $2 \%-2.6 \%$. The frequency of calm periods halved in central and eastern

${ }^{26}$ Data source: Lithuanian Hydrometeorological Service. 
Lithuania with their probability reaching just $2 \%$. Probability of calm periods without wind in the maritime region increased from $0.7 \%$ to $1.4 \%$.

Forecasting by variations in wind direction and intensity, the western region winds are to be more frequent on the Baltic Sea coast. In the summer NW wind should blow, while other seasons would see SW winds more often. Average wind velocity is thought to change insignificantly in $21^{\text {st }}$ century, but it can increase slightly on the coast. This is necessary for planning wind power plants as an alternative energy source. The increased sea level and wind direction affect the inflow of saline water into Kuršiu Marios (the Curonian Lagoon).

The number of sunny hours per year on the Kuršiu Nerija (Curonian Sand Spit) and the coast (about $1860 \mathrm{~h}$ ) decreases going eastwards to 1690 hours. The months from May to August are most sunny (230-270 h per month, in average), the least number of sunny hours was observed from November to January (30-45 h per month). During last 16 years (1991-2006 m.), if compared to 1961-1990, the number of sunny hours grew by $80-200 \mathrm{~h}$ with the maximum in west and south-west Lithuania and the least growth was in the east (Fig. 8). These additional prognoses are related to development of recreation and tourism in certain regions. Nevertheless, too high duration of UV radiation (erythemal 280-315 $\mathrm{nm}$ radiation) can cause skin and eye diseases, weaken immune system (due prognosis and information of people is necessary).

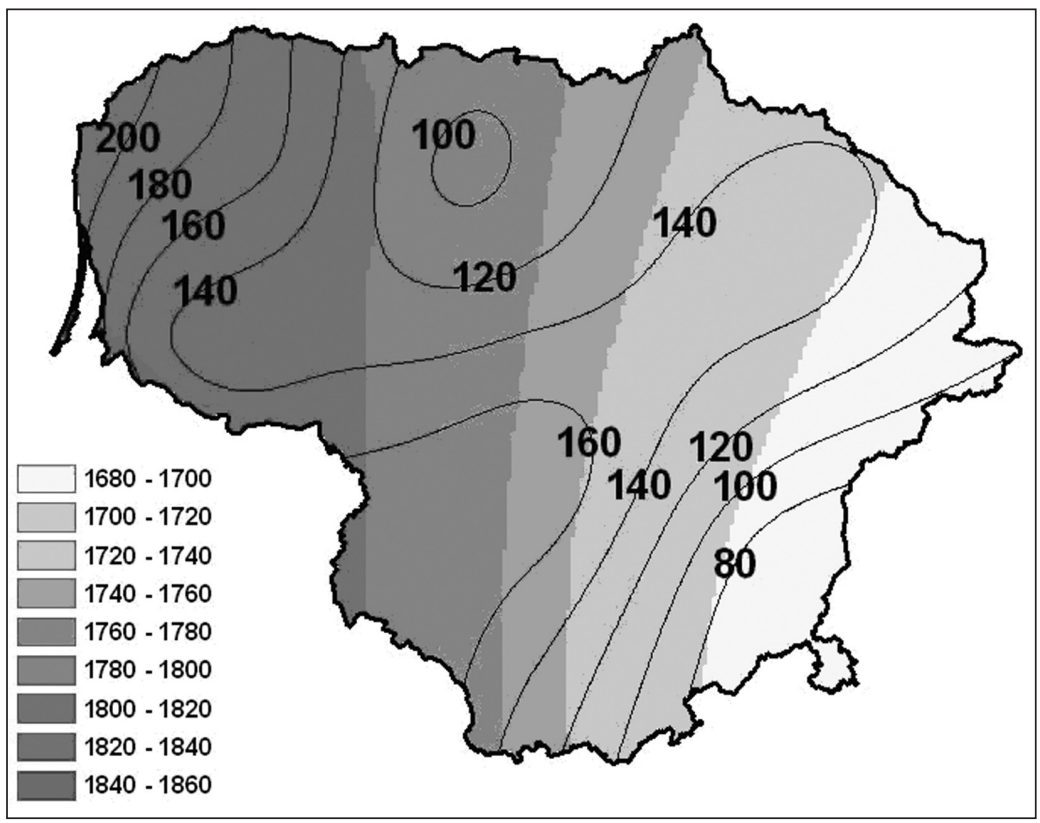

Figure. 8. Mean numbers of sunny hours per year in 1961-1990 m. (colour scale). Isolines show difference in sunny hours between 1991-2006 and 1961-1990 ${ }^{27}$

\footnotetext{
${ }^{27}$ Data source: Lithuanian Hydrometeorological Survey.
} 
The available climate change modelling results indicate that mean annual sunshine duration in the $21^{\text {st }}$ century is to grow. The growth is expected to be the highest from May to September, but in winter it should be lower. Moreover, the forecasts show that, due to territorial unevenness in sunshine intensity, the sun in Vilnius will shine half shorter than at present.

\subsection{Changes in the State of Surface and Subsurface Water Bodies in Lithuania}

Environmental problems related to the state of groundwater should be mentioned separately, since it is the main source of drinking water $(\sim 7 \%$ of all groundwater used). There are no exact data about fresh water demand by the mankind for the next 20-25 years, but approximate assessment shows it might be $\sim 28,000 \mathrm{~km}^{3}$ per year. Lithuania is one of few countries, where people drink only groundwater. Climate change should be linked not only with the world ocean level variation but also with that of the groundwater. Soil degradation causes fall of shallow groundwater level and draining of larger areas. There are also specific environmental problems related to groundwater-with its balance changing the living niche conditions also change thus partly causing the degradation of biological variety, as well losses in agriculture and forestry. Atmospheric pollutants raise the acidity of precipitation and groundwater; fortunately, up to now the acidity is neutralised in surface deposit layers in Lithuania. The dispersed and point pollution of the land surface can cause variation of shallow and deep groundwater chemistry. In Lithuania, due to wrong choice of dug wells with regard to pollution sources and their improper control, more than $30 \%-40 \%$ of dug wells in the villages and settlements contain water polluted with nitrates $(>50 \mathrm{mg} / \mathrm{l})^{28}$. The state of groundwater, especially shallow one, was found to be depending directly on meteorological conditions, which were unfavourable during the last two decades and causing lower groundwater levels, which were the lowest in 2003, 2004 and 2006.

Climate change, intensifying use of groundwater, and soil amelioration are thought to disturb the water balance in the North Lithuanian karst region and changed the rate of gypsum bed denudation, thus creating conditions to more rapid formation of underground voids and sinkholes. All this worsened the conditions for territorial planning and use, as well as made life of local people less safe ${ }^{29}$.

Due to climate change, surface water quality problems appear in Li-

\footnotetext{
${ }^{28}$ Drulytė I., „Vanduo ir sveikata (kokybè, sauga ir priežiūra)...['Water and Health (Quality, Protection, Treatment'] ", Seminar: „Vanduo kasdieniam vartojimui ir pramonés poreikiams - efektyviausi aprūpinimo ir tvarkymo būdai" ['Water for Everyday and Industrial Use-Most Efficient Supplay and Treatment Ways'], Vilnius, 2007, p. 3-27.

${ }^{29}$ Lietuvos gamtinè aplinka, būklè, procesai ir raida [Lithuania‘s Natural Environment, Its State, Processes and Development], Aplinkos apsaugos agentūra [Environment Protection Agency], Vilnius, 2008, 238 p.
} 
thuania, with the eutrophication of Kuršiu Marios Lagoon and some lakes and the overgrowth of river channels in all basins being the crucial one. The reasons of these phenomena are mainly related to human activities causing large amounts of waste to enter the rivers and brooks running via towns and settlements. Untreated wastewater from living houses having no centralised sewerage creates a problem because it often reaches surface water bodies. Since the wastewater is not diluted enough, even when wastewater treatment plants are arranged according to European Union standards, the pollutant content exceeds maximum permissible concentrations in river water. Such situation is, for instance, in the Kulpe River at Šiauliai.

All river basins in Lithuania are international; therefore the pollutants being brought from other countries make a negative impact on the quality of Lithuanian rivers. The situation is aggravated by the fact that pollutants come from Russia and Belarus, which are not obliged to keep to the EU directive requirements. Thus, additional hazards appear for river biota, stability of hydrological systems, recreation and, sometimes, human health. For instance, appearance of bloodsucking midges, due to climate change, and the outburst of their population in southeast Lithuania is a serious problem not only for wild and house animals but also for recreation in the Druskininkai resort. ${ }^{30}$

In order to improve conditions for agriculture, in Soviet times, small rivulets were drained on a wide scale. Therefore, these measures changed dramatically the stream channel processes, river load composition, water hydrochemical and hydrophysical properties and aquatic biota. Most of such streams were in the central and northern regions of Lithuania-the key zone of Lithuania's agriculture. Such radical transformation of the surface affects greatly water balance and extreme runoff values and, hence, the production intensity of the agricultural complex.

Among other new factors (input of nutrients from wastewater and surface drainage, etc.) inducing eutrophication of Lake Drūkšiai, constant warm water inflow from nuclear power plant should be mentioned, as all this changed the fish biomass, total and of separate species. River channels overgrew in central Lithuania, where the effect of nutrient inflow from agricultural fields is enhanced by slow water flow and regime of higher temperatures. Therefore, thermophilic fishes prevail in the rivers.

Due to climate change and unfavourable habitats, areas suitable for cold water fishes (salmonidae, coregoninae, gadidae) shrunk significantly. Due to additional man-made barriers (dams) the spawning areas decreased significantly for migrating fishes (salmon, bull-trout, vimba).

Although during the last decade, a tangible progress is made in reducing water pollution and supplying good-quality water, but wastewater treatment and drinking water perfecting still is one of the key problems. To deal with

\footnotetext{
${ }^{30}$ Žalakevičius M., Klimato kaitos poveikio ekosistemoms ir jų sudètinėms dalims pastarujų dešimtmečiu tyrimai Lietuvoje ['Investigations of Climate Change Impact on Ecosystems and Their Components during Last Decades'], ,Biota ir globali kaita -II" ['Biota and Global Change-II'], Vilnius, 2008, p. p-31.
} 
them and control water quality and quantity, the legal base with the administrative and control structures is formed and regularly improved keeping to the European Union directives: General Water Policy, Drinking Water, Nitrates, Urban Wastewater, Freshwater Fishes, Bathing, etc.

In 1990, according to the then requirements in Lithuania, only $25 \%$ of collected wastewater was treated. With the restoration of independence, the focal attention of the government in the environment protection field was paid to urban wastewater treatment. During last 14 years, the investments into the construction of wastewater treatment plants of the biggest cities made, was about $1.2 \mathrm{bn}$ LTL, therefore now $69 \%$ of wastewater collected by centralised systems is treated. Wastewater from small towns and villages is not sufficiently treated or untreated; this portion is small if compared to the total wastewater collected, but the number of such units is very high, thus, the relative cost (e.g., investment demand per capita) to solve this problem is considerably higher than that in the big cities. In Lithuania the centralised collection and treatment of wastewater is available only for $58 \%$ of population, and in rural areas this indicator is pretty lower. The problem is to remain in the nearest future, and the climate change (air temperature) will worsen the state of waters polluted. From 1990 there was nearly no consideration shown for the rural water treatment units. Municipal enterprises took over these units from kolkhoz and sovkhoz administrations without any inventory and assessment of the property. Due to economic hardships and great number of small water supply enterprises, about a third of Lithuania's population cannot obtain drinking water from reliable (controlled) sources. The preliminary investigations show that up to $60 \%$ of rural population uses drinking water of low quality and is hazardous especially for children.

The situation is worsening due to poor economic state of rural regions. People are incapable to pay for water supplied at such sums, which were sufficient to maintain the old and inefficient water supply system. Therefore, many such systems are not operated now, and people are forced to find alternative drinking water sources. The situation of wastewater treatment in the villages is even worse.

With means lacking to repair the installations, improper maintenance, old unproductive or dismantled equipment, and smaller volumes of wastewater, about 600 treatment units in the settlements do not operate or they treat the wastewater without reaching the quality requirements.

Lithuanian river water investigations carried out in 1992-2006 showed an obvious tendency of decrease in total nitrogen, total phosphorus and ammonium nitrogen ( $\mathrm{N}_{\text {total }} \mathrm{P}_{\text {total }}$ and $\mathrm{N}_{\mathrm{NH} 4}$ decreased by $2 \mathrm{mg} / \mathrm{l}, 0.1 \mathrm{mg} / 1$ and $0.2 \mathrm{mg} / \mathrm{l}$, correspondingly). However, nitrate content in river water was growing from 1986 to $2004 \mathrm{~m}$. and only from 2005 it showed significant fall. This could be due to the decrease in river water runoff (a continuing descent of shallow groundwater level) and smaller washout of nitrogen compounds from agricultural fields.

About the content of organic matter in water it can be judged according to Biochemical Oxygen Demand in 7 days $\left(\mathrm{BOD}_{7}\right)$, dissolved oxygen quantity necessary to oxidise biochemically the organic matter. 
The analysis of the 1986-2006 period shows marked tendency of decrease in $\mathrm{BOD}_{7}$, its content in Lithuanian river water fell by $1 \mathrm{mgO}_{2} / 1$.

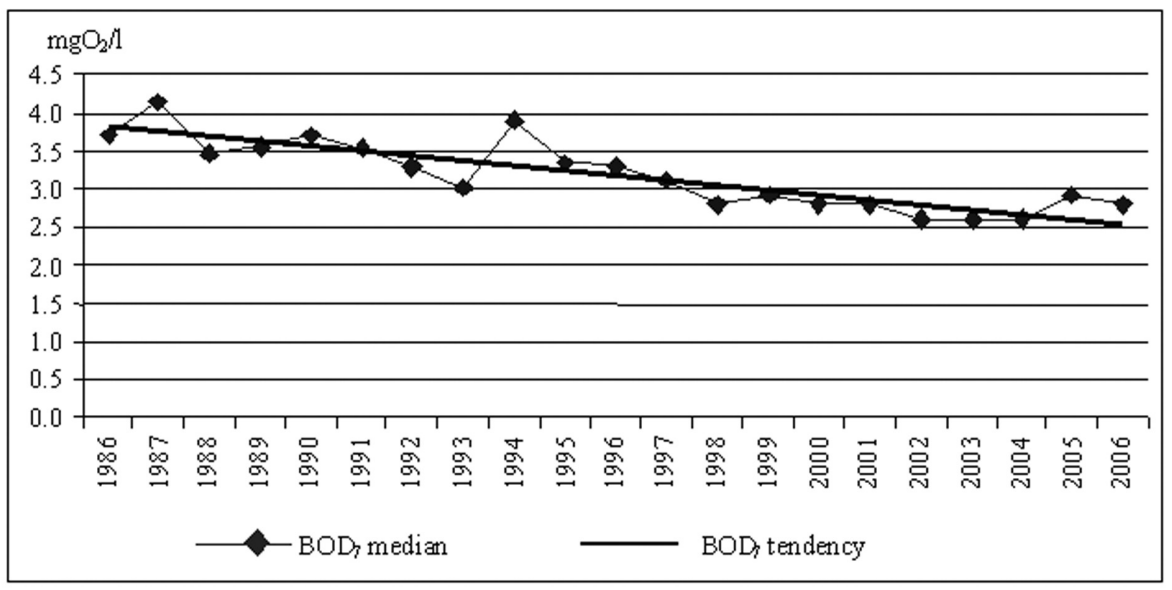

Figure 9. Tendencies in changes of $\mathrm{BOD}_{7}$ content medians in 1986-2006 m. ${ }^{31}$

According to conditionally chosen concentration intervals, total nitrogen in $50 \%$ investigation sites on the rivers ranged from ranged from 0.75 to 2.5 $\mathrm{mg} / \mathrm{l}$. it should be noted that from 1995 total nitrogen values exceeding 7.5 $\mathrm{mg} / 1$ decreased by $10 \%$, and this makes up only about $10 \%$ of all river investigation sites. Total phosphorus values were lower than $0.1 \mathrm{mg} / \mathrm{l}$ in about $50 \%$ of all river investigation sites, ranged from 0.1 to $0.25 \mathrm{mg} / 1$ in $40 \%$ sites, and exceeded $0.5 \mathrm{mg} / 1$ in $10 \%$ sites. $\mathrm{BOD}_{7}$ values ranged from 2 to $3.5 \mathrm{mgO}_{2} / 1$ in more than $50 \%$ of river investigation sites.

Before $2002, \mathrm{BOD}_{7}$ values exceeded $5 \mathrm{mgO}_{2} / 1$ in about $20 \%$ of river investigation sites, and only after 2002, number of such sites decreased to $10 \%$. From $1992, \mathrm{BOD}_{7}$ values were observed lower than $2 \mathrm{mgO}_{2} / 1$ in $20 \%$ of all investigation sites.

Maximum values of total nitrogen, total phosphorus and organic matter $\left(\mathrm{BOD}_{7}\right)$ are determined in the river sites downstream the towns and in low water streams accepting untreated wastewater from towns (Obele, Kulpe, Sidabra, Šalčia, Laukuva, Lèvuo mouth area, Nevėžis, intensive agriculture areas and the large rivers of Nemunas and Neris.

Rivers having clean water, i.e. organic matter, nitrogen and phosphorus values do not exceed or exceed slightly maximum permissible concentrations (MPC), are these: Minija, Jūra, Šešupè, Šventoji, Akmena upper reaches, Veiviržas, Šelmena, Žeimena, Būka, Strèva, Bartuva, Birveta, Laukesa and Šventoji falling into the Baltic Sea.

The studies performed on Lithuania's river water in 1992-2006 show

${ }^{31}$ Data source: Environment Protection Agency. 
obvious decrease tendencies according to copper, nickel, mercury and lead content with especially sharp fall tendency for nickel and chromium from 1997. Copper, nickel and lead content rose only in 2002. Increase of heavy metals was favoured by a decrease in water volume in the rivers and, hence, a lower dilution of them.

When analysing variations of Lithuania's river water indices during the 1992-2006 period, we can see increase in zinc content in 2001-2004 and its sharp decrease starting from 2005.

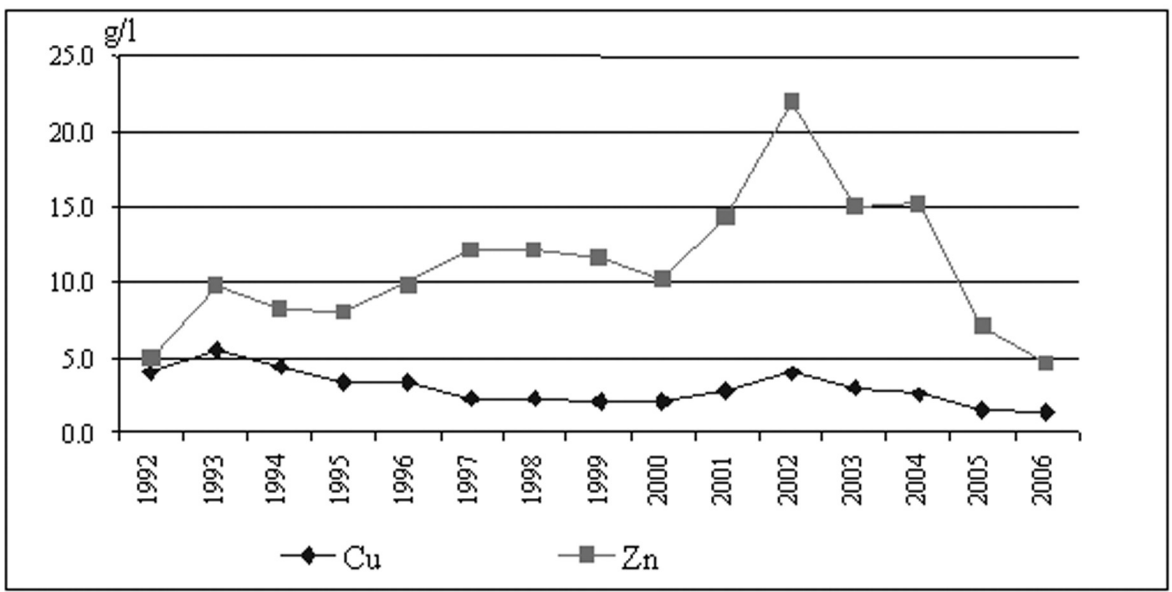

32

Figure 10. Tendencies in changes of copper $(\mathrm{Cu})$ and zinc $(\mathrm{Zn})$ content annual medians in 1992-2006 ${ }^{21}$

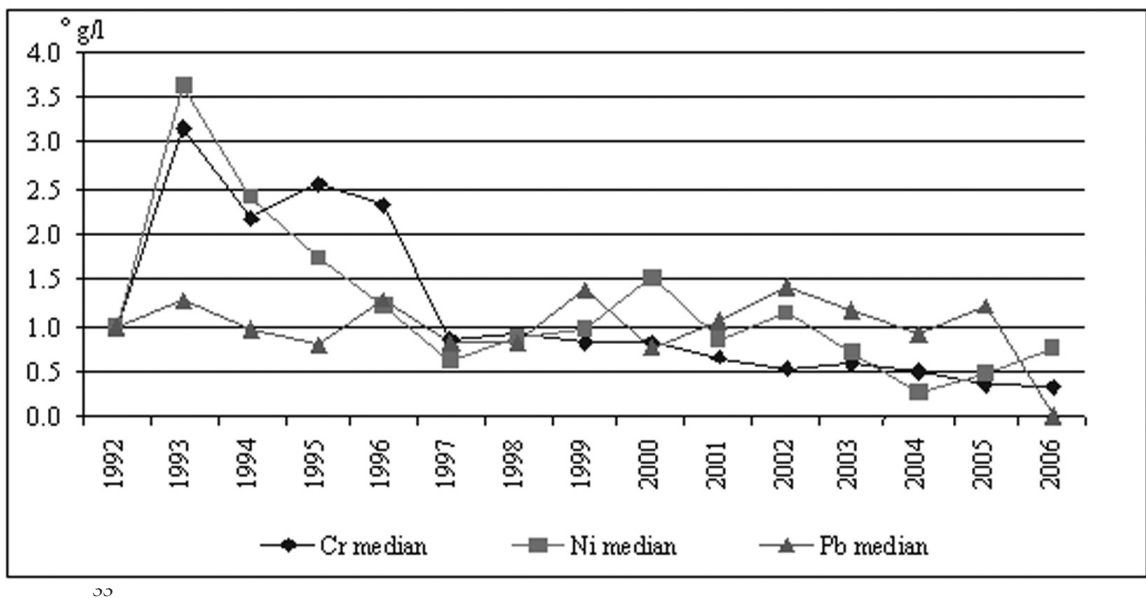

Figure 11. Tendencies in changes of chromium (Cr), nickel (Ni) and lead (Pb) content annual medians in 1992-2006 ${ }^{22}$ 
In 1997-2004 m. simazine was detected in Nemunas only once $(1.15 \mu \mathrm{g} / \mathrm{l})$, lindane determined in Nemunas, Lokysta and Nemunèlis ranged from 0.01 to $0.06 \mu \mathrm{g} / \mathrm{l}$. DDT was detected in 23 cases in 15 rivers ranging from 0.01 to 0.96 $\mu \mathrm{g} / \mathrm{l}$. Phenols (pentachlorphenol) were determined in nine rivers (Nemunas, Šešupè, Venta, Mūša, Sidabra, Nemunèlis, Lèvuo and Birvèta) with their content ranging from 0.01 to $0.4 \mu \mathrm{g} / \mathrm{l}$. Other hazardous substances were detected in 1997-2004 only very rarely or they were undetected. ${ }^{29}$

Analysing data on species composition of river hydrobionts (macrozoobenthos) for the period of 1994-2006 we can see that water quality improved, i.e. the number of river sites under the state monitoring the Class I (very clean water) and Class II (clean water) increased significantly. From 2002, about $11 \%$ of rivers studied belonged to the Class I, while in 1994-1998 and 2001, no Class I sites were detected. In 1994, the Class II sites comprised 9.4\%, while in 2006, such sites made up $67 \%$. In 1994 there were $26 \%$ of Calls V river sites (heavily polluted water), but in 2006 they made up only 1\%.

The data show long term tendencies of a decrease in contents of basic pollutants from 1992.

\subsection{Variation in Kuršių Marios Lagoon and Baltic Sea Nearshore Water}

The Lithuanian part of the Baltic Sea shoreline makes just about $100 \mathrm{~km}$, and its territorial and economic zones make up only $1.5 \%$ of the total Baltic Sea area. Lithuania also has $25 \%$ of the Kuršių Marios (Curonian Lagoon) area $\left(413 \mathrm{~km}^{2}\right)$, i.e. a part of its central and northern areas with the national port in the Klaipeda Strait, where the most urgent water pollution and eutrophication problems occur.

Kuršiu Marios is a eutrophicated water body affecting the state of the Baltic Sea near the shore. The quality of the Kuršiu Marios water depends on municipal, industrial (with rain) wastewater, as well as agricultural, shipping and other-type pollution and nature conditions. Water from about $75 \%$ of Lithuania's area falls into the lagoon, thus draining $5.8 \%$ of the Baltic Sea river basins area. The increase in biological productivity is determined by high nutrient (nitrogen, phosphorus) input with wastewater from towns and settlements by Nemunas and other rivers, from the atmosphere and other pollution sources. Other specific pollutants, such as oil hydrocarbons and heavy metals, also reach the Kuršiu Marios lagoon and the Baltic Sea. Due to the ability of some of them to accumulate in living organisms, there is a potential risk for human health as well.

According to the long-term investigation data, saline water enters the lagoon from the Baltic Sea more often than before. During all the year, there is dynamical water exchange in the Klaipeda Strait between the sea and the lagoon. A major part of fresh water brought by the rivers into the lagoon flows 
to the Baltic Sea. Salinity data obtained at the Juodkrantè and Nida posts situated at the lagoon shores show rather frequent invasions of saline water into the Kuršiu Marios. From 1981, the salinity increased by 0.31 \%o at Juodkrante் (about $29 \%$ ) and by $0.01 \%$ o (about $12.5 \%$ ) in the central part of the lagoon at Nida. In 1995-2005, number of days with fresh water $(<0.5 \%$ ) at Juodkrante was by $7 \%$ lower than that in 1984-1994. ${ }^{29}$

The increase in lagoon water salinity is caused mainly by hydrometeorological conditions, i.e. prevailing and becoming more frequent stormy NW winds forming a wind-induced surge in the south-eastern part of the Baltic Sea, changes in North Atlantic atmospheric circulation, lower runoff of the Nemunas River and climate change-related rise of world ocean level. Dredging in the Klaipeda harbour also creates conditions favourable for sea water being denser to penetrate into the lagoon and stay there longer. Frequent invasions of saline seawater into the lagoon may be hazardous for biota. Freshwater species of aquatic flora and fauna are replaced by brackish water species with significantly lower variety (even more lower from the economic viewpoint) as new fish species are competitive to the local fishes. Climate change makes ice cover lasting shorter in Kuršiu Marios and the lower reaches of the Nemunas. Terms of fish migration and spawning change. Due to low water level and high temperature in July and August, fish migration to the deeper part of the lagoon beyond the Russian Kaliningrad Region border is observed-the outcome unfavourable for Lithuanian fishermen. ${ }^{34}$

Water quality in the Lithuanian near shore areas of the Baltic Sea is caused mainly by water flow from the Kuršiu Marios Lagoon, wastewater disposal into the sea, directly or indirectly via rivulets, as well as quality of water in the rivers running into the sea, In summer, during the eutrophication period, due to decay of algae, recreation and angling conditions worsen in the Klaipeda Strait, where pollutions is inevitable because of port activities, in the harbours of smaller rivers and other sites polluted with wastes. Organic chlorine pesticides are still detected, since such pesticides as DDT and $\mathrm{HCH}$ accumulate not only in water and deposits, but also in biota. However, several decades ago, when these substances were banned, only low contents are detected in biota, and a tendency of further decrease is observed, thus indicating that these substances are successfully being removed from the natural environment.

\subsection{Baltic Sea Shore Erosion}

The state of the Lithuanian seaside depends on interaction of natural and anthropogenic factors. The shore zone is negatively affected by an unbalanced performance of human activities, as well as natural phenomena (for example

\footnotetext{
${ }^{34}$ Repečka R., Globaliosios kaitos poveikis žuvų ištekliams it tvarus žuvų išteklių vartojimas [Impact of global change on fish resources and sustainable use of fish resources], „Biota ir globali kaita I” ['Biota and Global Change'], Vilnius, 2007, p. 197-210.
} 
storms, hurricanes, etc.), which erode the shores, make beaches narrower, and speed up dune movement. The climate change in the $21^{\text {st }}$ century is expressed not only in more frequent extreme weather cases, but also in more rapid rise of water level as the tendencies unfavourable for Lithuania's Baltic shores. With water level rising, larger land areas suffer the eroding impact of waves with more rapid changes of the shoreline and more frequent invasions of seawater (especially, together with concurrent winds favourable for such a phenomenon) into the Kuršiu Marios Lagoon. The Baltic Sea shore erosion induces some serious problems related to:

- Shrinking Lithuania's area;

- Contracting of recreational space and worsening of its state;

- Secure maintaining of hydro-engineering units;

- Risk for the buildings situated near to the seashore and infrastructure.

The best indicator of the Baltic Sea shore state is the seashore dynamics that shows whether the shore-composing matter is eroded or accumulated and that is calculated using the data on the mean long-term sea level, as well as shore changes in time and space. It reflects best the long-term trends in shore state dynamics (after local and seasonal shore state variations are excluded). This is the basic indicator for substantiation of environment protection measures planned.

The data available shows that the fastening of Palanga promenade pier had augmented the shore zone by $450 \mathrm{~m}$ and favoured formation of a wide fine sand beach. In 1997-1998, when a part of this shore fastening was removed, sand erosion took place under the pier, and hurricane waves washed again the sandy shore with the outcome being three times narrower beach. Due to Klaipeda harbour gate reconstruction in 2001-2002, the erosion became more active at Melnrage and Kopgalis. Moreover, due to weak fastening works the shore erosion zone expands north of Kaliningrad. Moreover, the shore erosion on the mainland is more active.

In 1961-2004, mean annual water level variations in the Klaipeda Strait and the Kuršiu Marios at Nida show water level rise tendency. From 1997, mean annual water level is higher than that in 1961-1990. In 2004, it exceeded the long term mean annual level by $15.6 \mathrm{~cm}$ at Nida and $12.9 \mathrm{~cm}$ in the Klaipeda Strait. Lately, the water level rise is directly related to such problems as shore erosion, security of the hydro-engineering, land inundation and ecological balance disturbance. Calculations showed that sea level rose by $15 \mathrm{~cm}$ during the last century. 


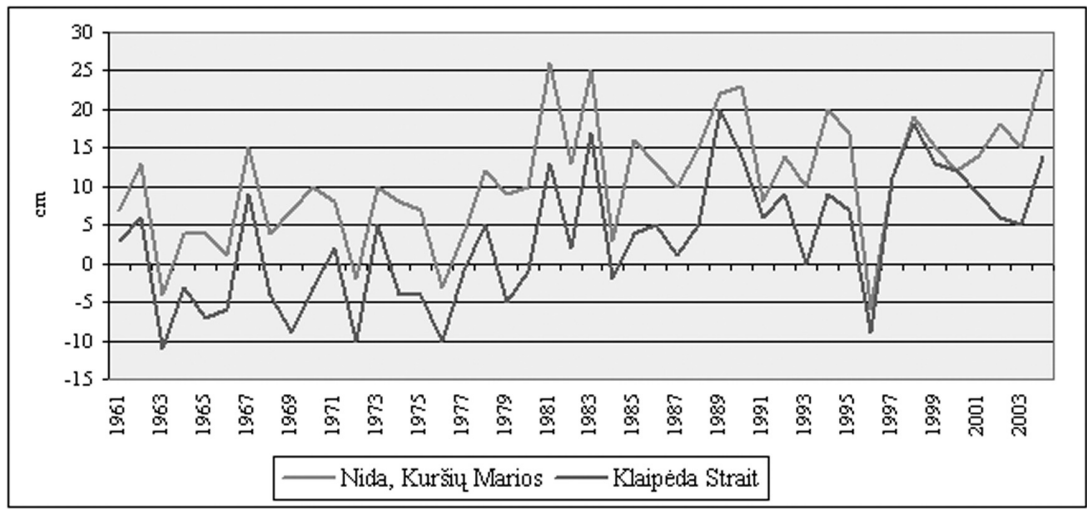

Figure 12. Variations of mean annual water level in Klaipeda Strait and Lagoon of Kuršių Marios at Nida in 1961-2004 ${ }^{35}$

The shores suffered catastrophic erosion by the hurricanes in 1967, 1983, 1999 and 2005, when water level rose above the $150 \mathrm{~cm}$ mark. The slopes on the mainland shore were fastened in 2003-2004, which slowed the erosion process. If the area near the shore dune ridge were not fastened with tree branches, the 2004 storm waves would erode this protective ridge at Palanga by $10 \mathrm{~m}$ more. From 1998, even $40 \mathrm{~m}$ of the dune ridge (of the total $100 \mathrm{~m}$ ) was eroded in Palanga at "Voveraite". Each year the cliff at Olando Kepure retreats by two metres. The hurricane Anatoly that ravaged the Baltic Sea coast, swept away 30 ha of dune ridge, and later 13.5 more hectares had been lost, with only $10 \%$ regained up to now.

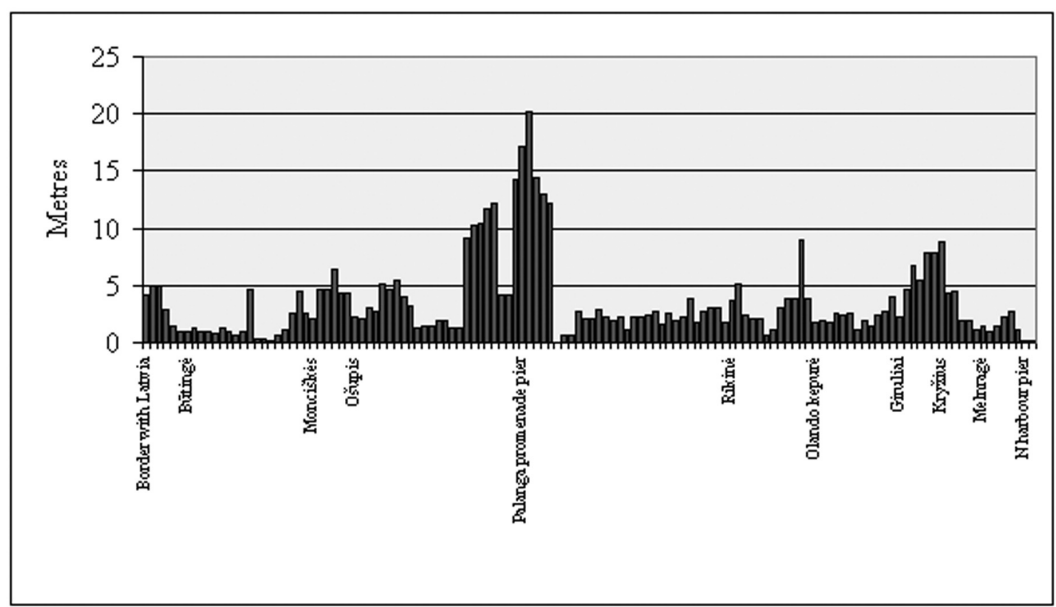

Figure 13. Seashore sand total losses caused by erosion in the mainland part of the Baltic Sea coast in 2000-2004 ${ }^{36}$

\footnotetext{
${ }^{35}$ Data source: Centre for Marine Researches.

${ }^{36}$ Data source: Centre for Marine Researches.
} 
In 2002-2004, due to intensification of cyclone activities, shore erosion strengthened nearly on all length of Lithuania's seashore, and the extent of eroded shores exceeded the long-term values. The most intensive erosion takes place in the shore sites situated at the Latvian border, the Palanga promenade pier (from Rąžès Stream to Birute Hill), Olandų Kepure and Kopgalis. During the last 30 years (1976-2006), the total length of lost accumulative shores on Lithuania's seacoast made up $1100 \mathrm{~m}$ per year, and the total length of erosional shores rose by $367 \mathrm{~m}$ per year. ${ }^{29}$

The state of the shore is predicted to worsen in the near future. Shore erosion intensity will be favoured by the rise in air temperature, as warming winters usually determine in our latitudes. Taking into account the present dynamics in certain shore zone sites and their potential changes, the most problematic shore sites can be distinguished on the Lithuanian seacoast.

The recreation load in the Palanga zone is increasing each year, the development of urban areas is intensifying. Due to the deficit in deposits on the shore and areas near the shore, the Palanga shore zone is predicted to be vulnerable to the climate change.

The Klaipeda recreation zone also experiences constantly increasing recreational load. The planned construction of deep harbour and climate change may cause the morphological state of the zone to worsen. Under the present geodynamical situation and due to strengthening erosion on the Kuršių Nerija sand spit, the most problematic is the shore site at Kopgalis.

\subsection{Impact on Biological Variety and Man}

The pressure of climate change on biological variety is going on constantly via mechanisms specific for each species, but the living nature systems (for example populations, communities, etc.) are not always able to preserve their species composition and variety. During the present period, the losses are more common than the appearance of new species favourable for humans or adaptation of the former ones. With the natural environment changing in Lithuania, new potential risks arise, such as:

- Degradation of present ecosystems/habitats: retreat and/or disappearance of species, spreading of new exotic species, including undesirable ones causing new diseases and spreading them, new food chains in the ecosystems and potential consequences (e.g., lower productivity of ecosystems), which can be difficult to prognosticate;

- Likely rapid change of plant associations and forest ecosystems will change conditions for fauna, especially amphibians, insects, reptilians, and birds, areas of which will dramatically change, followed by rapid disappearance of species and further change in community composition;

- According to temperature optima, the pace of succession for land and water invertebrates and other communities will change; species disappearance rate will depend on the pace of climate warming and the rate of scattering and/or spreading of these species; 
- Due to changed conditions, rare species will leave the protected areashence, new risks and barriers will appear to protect these species; many environment protection and management measures commonly applied now will not be efficient, therefore, new concepts, methods and measures (reform of protected areas network) will be necessary; and there will be an especially high demand in the international protection and international cooperation to create and regularly revise general systems and networks of protected areas.

Discussing environmental factors causing a significant impact on certain national economy sectors linked with biological variety (forestry, fisheries, partly agriculture), the potential changes can be stated. Given further increases of environment pollution and climate change, two different processes are expected to take place in the forest ecosystems: (1) due to increase in content of ozone and sulphur oxides, as well as acidification of atmospheric precipitation, the state of tree canopy is to worsen and structural relations of micro-arthropods in the soil are to increase, whereas the variety of macrobenthos in forest hydro-systems is to lessen, etc.; (2) due to increase in atmospheric precipitation and air temperature, the resistance of these biota components to pollutants is to be higher (wider species variety, larger numbers of individuals in the communities). ${ }^{37}$

Temperature and precipitation conditions are to determine different formation of population's needle-eating and young forest stand pests. Species of forest pests (various weevils, pine moth, pine beauty moth, conifer sawfly) are affected by differences in both temperature and precipitation. Warm and dry weather intensifies expansion of pest focuses and rapid growth of population. This is well seen in the data of the last two decades.

Heat and cold waves, or some other long lasting phenomena (droughts) are to impact severely productivity of plants (especially in agriculture) and cause economic losses, new problems related to introduction of new adaptive (to changing climate conditions in separate regions) breeds as well as formation of new agriculture strategy.

The majority of meteopathology experts say that nearly all meteorological factors can raise meteotropic $\mathrm{c}^{38^{*}}$ reactions in the organism. Atmospheric pressure variations and winds are of great importance. Influence of separate meteorological factors on human health is not clear enough. Variations in electromagnetic field intensity can change bioelectric activity of tissues and organs. Statistical data show that cardiovascular diseases flare up with falling atmospheric pressure; hypertensive crises, strokes and heart attacks become more often.

\footnotetext{
${ }^{37}$ Sąlygiškai natūralių ekosistemų kompleksiškas monitoringas [Comprehensive monitoring of conditionally natural ecosystems], 2006, Aplinkos apsaugos agentūra [Environment Protection Agency], Vilnius, p. 97-98.

${ }^{38^{*}}$ Meteotropic-related to meteorological conditions, weather, climate
} 
With appearance of new species the spreading of infectious diseases become more probable. With warming weather appearance and transfer of infectious diseases and their carriers with water and food accompanied by disturbance of local ecological balance is more likely.

Due to climate warming and pollution of the atmosphere with chemical compounds and biological substances (pollen, spores, etc.) cases of asthma and allergic reaction are more often observed.

Series of scientific works and studies have been performed in the world to find out the impact of climate factors on human mortality and hospitalisation for heart attack or stroke. Now, with climate rapidly changing, such studies become more important for both meteolabile ${ }^{39^{*}}$ people and clinicians. People having blood pressure disturbance are most vulnerable to changes in atmospheric pressure and high winds, especially in the case of association of these both factors, as well as atmospheric fronts. Heart attacks, as a rule, occur with cold front passing, usually, at night or morning. Stroke cases are vulnerable to daily extreme variations in atmospheric pressure ${ }^{40}$. The association between air temperature and the risk of stroke and acute myocardial infarction can be explained by such factors as changes in clotting mechanisms, lipid levels, and blood pressure. However, seasonal variation in lipid levels seems to be an unlikely explanation for the large seasonal variation in the incidence of stroke recorded in the study.

Blood pressure shows marked seasonal variation, it is higher in winter (colder) months. The increased blood pressure is a strong risk factor for stroke. ${ }^{41}$ The strongest meteotropic reactions are typical of those having disturbance of blood pressure, myocardial ischemia, cerebral atherosclerosis and rheumatism.

About $50 \%-80 \%$ of people with cardiovascular diseases are meteolabile. Taking this into account, the analysis of dependence of EMT ${ }^{42^{*}}$ admissions for myocardial and brain infarctions, as well as stroke cases on such climatic parameters as daily air temperature, atmospheric pressure and their variation, relative air humidity and sun radiation in 2005-2007 in Vilnius City showed the following results: the increase of EMT admissions for myocardial infarction took place at low diurnal temperatures and high amplitudes of air temperature variations from day to day (-10 degrees or even more). Moreover the correlation of these climatic parameters showed high confidence coefficient $-\mathrm{p}<0.001^{18}$. EMT admissions for myocardial infarction in 2005-2007 in Vilnius City were most frequent due to low daily air temperature (when average daily air tem-

\footnotetext{
${ }^{39^{*}}$ Meteolabile - sensitive, with pathological reaction to meteorological conditions.

${ }^{40}$ (Klimato kaitos poveikio šaliai îvertinimo studija ir pasekmių švelninimo strateginis planas, 2007) [A Study on the Assessment of Climate Change Impact on the Country and Its Outcome Mitigation Strategic Plan] (in Lithuanian), (http://www.bmj.com/cgi/content/full/329/7469/760-d)

${ }^{41}$ Prušinskaitė A., 2008, Klimato įtaka kai kurių ligų paūmėjimui, bakalauro darbas [Influence of Climate on Some Disease Flare-up, Bachelor Thesis], VU, GMF, Ekologijos ir aplinkotyros centras [Centre for Ecology and Environmental Studies], 47 p.

42* EMT - emergency medical treatment
} 
perature is below $\left.-10^{\circ} \mathrm{C}\right)$, extreme variations of atmospheric pressure $(<970 \mathrm{hPa}$ or $>1020 \mathrm{hPa}$ ), as well as duration of sun radiation (at sun radiation lasting $0 \mathrm{~h}$, number of admissions increased by 1.5 times per month). ${ }^{39}$

EMT admissions for brain infarctions in 2005-2007 in Vilnius City showed no association with the climatic factors studied. Nevertheless, at high average daily temperatures $\left(>25^{\circ} \mathrm{C}\right)$, low relative air humidity $(<41$ proc.) and high atmospheric pressure $(>1020 \mathrm{hPa})$ a slightly higher number of admissions have been fixed. EMT admissions for stroke in 2005-2007 in Vilnius were best related to the relative air humidity; so, with the increase of humidity the number of admissions for stroke increased $(\mathrm{p}<0.01 ; \mathrm{r}=0.67)$ and with shorter solar radiation the number of admissions also increased $(\mathrm{p}<0.07 ; \mathrm{r}=-0.54)$. Seasonal distribution of EMT admissions was detected only for the cases of myocardial infarction-the number for admissions increased in winter and spring months.

\section{Summary}

By analysing the processes taking place, together with climate change and their perspectives in Lithuania's environment, it can be said that in spite of strategies and programmes approved for improvement of the environmental state and measures applied, climate change processes will go on. This is mainly due to global factors, not regional or single-state factors affecting the environment. Therefore, the scenarios of climate change will be imminently linked to the strategy the humans will implement to exist on the Earth and the related political, social and economic development. In fact, the development of the natural environment will be determined by two components-climate change and anthropogenic load intensity. Up to now we encountered the global problem of adaptation to the impact of climate change or impact-mitigating local solutions. These processes take place in the natural environment constantly, but the solution of this problem in separate social life spheres is quite a different thing.

Climate change processes in Lithuania already induce the intensification of extreme nature phenomena (storms, hurricanes), affect mean annual solar radiation duration and seasonal character, as well as UV radiation levels, Baltic Sea and Kuršių Marios Lagoon water level increase, eutrophication of surface water bodies and acceleration of their ageing, decline in biological variety, changes of species composition, productivity, appearance of undesirable and hazardous exotic species, air quality and near-surface ozone, pollution spreading in Lithuania's cities and other processes.

Climate change and anthropogenic load, affects environment pollution with all the outcomes of this process, general transformations and losses of landscapes and separate areas, depletion of nature resources, and other processes. Finally, this is extremely important for socio-economic and demographic development, technology innovations, management, and chiefly for human health. 
It should be acknowledged and understood that only the maximum cut of the negative impact of anthropogenic load on the environment and the implementation of balanced preventive measures to mitigate the inevitable outcome of nature degradation affected by climate change will help us to at least stabilise the state of natural environment in Lithuania and, hence, to partly preserve its valuables.

Vilnius, July-September, 2008 